\title{
PENGOLAHAN TEPUNG BAYAM SEBAGAI SUBSTITUSI TEPUNG BERAS KETAN DALAM PEMBUATAN KLEPON
}

\author{
Chairul Salim ${ }^{1}$, Vienna Artina.S ${ }^{2}$, Alisha Sekar Ayu ${ }^{3}$ \\ ${ }^{1}$ Sekolah Tinggi Pariwisata Trisakti, chairul.cs@gmail.com \\ ${ }^{2}$ Sekolah Tinggi Pariwisata Trisakti, viena.artina@ stptrisakti.ac.id \\ ${ }^{3}$ Sekolah Tinggi Pariwisata Trisakti, alishasekarayu@gmail.com
}

\begin{abstract}
ABSTRAK
Wanita yang bekerja memiliki risiko anemia lebih tinggi daripada pria yang bekerja. Penyebab Anemia dapat disebabkan oleh tekanan kerja, kelelahan dan penurunan zat besi (Fe) di setiap siklus menstruasi. Bayam adalah sayuran dengan kandungan zat besi atau besi paling banyak dibandingkan dengan sayuran hijau lainnya. Kandungan zat besi bermanfaat bagi penderita Anemia. Kandungan air namun yang terkandung dalam bayam mencapai $86,9 \%$ yang menyebabkan daya bayam kurang. Tepung bayam adalah salah satu solusi untuk memperpanjang umur simpan dan menjaga nilai gizi yang terkandung dalam bayam. Salah satu tepung bayam fungsional adalah sebagai pengganti dalam pembuatan Klepon. Klepon dibuat dengan persentase substitusi tepung bayam 30\%,60\%, dan $90 \%$. Berdasarkan $100 \%$ dan 30\% hasil tes hedonik dengan peringkat rata-rata 3,33 dan 3,27 menunjukkan tingkat yang sangat disukai dan $60 \%$ dengan nilai rata-rata 2,89 menunjukkan tingkat suka. Sedangkan hasil uji One Way Anova, menunjukkan bahwa penambahan tepung bayam tidak memiliki efek signifikan pada rasa dan rasa tetapi memiliki efek signifikan pada tekstur dan warna Klepon.
\end{abstract}

Kata kunci: Anemia, Tepung Bayam, Klepon

\begin{abstract}
Women who work have anemia risk is higher than men who work. Causes Anemia can be caused by work pressure, fatigue and decreased iron $(\mathrm{Fe})$ in every menstrual cycle. Spinach is a vegetable with iron or iron content of most compared to other green vegetables. Iron content is useful for patients with Anemia.Namun water content contained in spinach reaches $86.9 \%$ which causes short of spinach power. Spinach flour is one solution to extend the shelf life and maintain the nutritional value contained in spinach. One of the functional spinach flour is as a substitution in the manufacture of Klepon. Klepon is made with percentage of spinach flour substitution of $30 \%, 60 \%$, and $90 \%$. Based on $100 \%$ and $30 \%$ hedonik test results with the average rating of 3.33 and 3.27 shows a very liked level and $60 \%$ with an average value of 2.89 shows the level of likes. While the One Way Anova test results, showed that the addition of spinach flour has no significant effect in taste and flavor but has a significant effect on the texture and color of Klepon.
\end{abstract}

Keywords: Anemia, Spinach Flour, Klepon

ISSN: 2355-6587, e-ISSN: 2528-2220

http://ejournal.bsi.ac.id/ejurnal/index.php/jp 


\section{PENDAHULUAN}

Di era globalisasi ini, banyak sekali wanita yang lebih memilih menjadi wanita karir dibanding menjadi ibu rumah tangga biasa. Mereka melakukan pekerjaan baik di kantor maupun bidang lainnya. Adapula yang memilih untuk melakukan keduanya secara bersamaan. Dengan kata lain, seorang ibu rumah tangga juga menjadi wanita karir di kehidupan sehari-harinya. Menurut Data Badan Pusat Statistik (2013), persentase wanita yang telah menikah dan tetap bekerja atau tetap menjadi wanita karir setelah menikah di Indonesia pada tahun 2009 sebanyak $55,24 \%$, pada tahun 2010 sebanyak $55,73 \%$, pada tahun 2011 sebanyak $56,55 \%$, dan pada tahun 2012 sebanyak $55,83 \%$. Hal ini membuktikan bahwa lebih dari setengah penduduk wanita di Indonesia yang telah menikah, mereka tetap melakukan pekerjaan mereka sebagai wanita karir dan sebagai ibu rumah tangga sekaligus. Dengan kata lain, mereka memegang dua peran sekaligus, yaitu sebagai ibu rumah tangga dan sebagai wanita karier.

Hal ini tidak memungkiri bahwa wanita karier lebih beresiko mengalami anemia dibanding pekerja pria. Menurut Chaves et al, (2002:1257-1264)Hal ini terjadi karna setiap wanita memiliki siklus menstruasi setiap bulannya. Tekanan pekerjaan dan kelelahan serta kekurangan zat besi saat terjadi siklus menstruasi setiap bulan menjadi faktor yang menyebabkan para pekerja wanita atau wanita karir lebih memiliki resiko menderita anemia.

Menurut Riset Kesehatan Dasar (2008:151) menunjukan prevalensi anemia penduduk Dewasa Perkotaan pada tahun 2007 pada perempuan sebanyak $19,7 \%$ dan pada laki-laki sebanyak $13,1 \%$. Riset ini dilakukan secara berkali setiap 6 tahun sekali. Dan Menurut Riset Kesehatan Dasar (2013:256), proporsi anemia penduduk umur $>1$ tahun menurut karakteristik Indonesia pada perempuan sebanyak 23,9\% dan pada laki-laki sebanyak $18,4 \%$. Secara keseluruhan proporsi anemia di Indonesia mencapai 21,7\%.

Kegiatan sebagai wanita yang bekerja sekaligus menjadi ibu rumah tangga membuat ketergantungan dalam membeli jajanan adalah hal yang lumrah setiap hari. Karena padatnya kegiatan ibu rumah tangga di tambah dengan beban pekerjaan diluar sebagai wanita karir, banyak dari mereka yang tidak menyempatkan diri membuat makanan sebagai sarapan dipagi hari. Oleh sebab itu jajanan kue tradisional, seperti kue basah pun banyak dipilih karna mudah didapat dan harganya pun terjangkau.

Menurut Data Survei Sosial Ekonomi Nasional (2017), konsumsi makanan siap saji komoditi kue basah per kapita dalam rumah tangga per tahun adalah pada tahun 2010 sebanyak 40.984 porsi, 2011 sebanyak 41.297 porsi, 2012 sebanyak 30.869 porsi, 2013 sebanyak 35.822 porsi, 2014 sebanyak 36.239 porsi dan pada tahun 2015 sebanyak 64.918 porsi. Terjadi peningkatan yang sangat signifikan terhadap konsumsi kue basah ditahun 2015. Tingkat konsumsi Kue basah pun menjadi urutan kedua Hal ini dikarenakan di era modern ini, wanita yang memiliki peran ganda sebagai ibu rumah tangga serta wanita karir lebih memilih makanan siap saji di setiap aktifitas. Terutama untuk sarapan.

Mengkonsumsi jajanan seperti kue tradisional pun dapat ditinjau baik dari sisi positif maupun negatif. Dari sisi 
positif adalah memudahkan para wanita karir untuk mendapatkan jajanan dengan mudah, cepat, dan murah. Namun sisi negatifnya, mereka tidak mempertimbangkan asupan gizi seperti zat besi yang dibutuhkan bagi mereka yang mengidap anemia.

Anemia disebabkan karna kurangnya gizi serta pola makan yang tidak baik. Kurangnya zat besi dalam tubuh seringkali ditemukan saat gejala anemia menyerang. Seperti lemah, letih, lesu, lemas dan lunglai. Hal ini bisa menurunkan konsentrasi dalam bekerja dan kurang maksimalnya pekerjaan mereka baik sebagai wanita karir maupun sebagai ibu rumah tangga. Untuk mencegah anemia dapat dilakukan dengan cara pola hidup sehat, olahraga teratur serta mengkonsumsi sayuran hijau segar yang banyak mengandung zat besi . (Tria, 2005)

Salah satu sayuran hijau yang memiliki zat besi tinggi ialah bayam. Tanaman bayam adalah salah satu jenis sayuran komersil yang mudah diperoleh baik di pedesaan maupun diperkotaan. Mulai dari pasar hingga swalayan. Bayam merupakan sumber vitamin $\mathrm{A}, \mathrm{C}, \mathrm{Fe}, \mathrm{Ca}$ dan K. Kandungan Fe atau Zat besi pada bayam pun lebih tinggi 2 kali lipat dari sayuran lain. (Pracaya dan Kartika, 2016:87)

Sebagai komoditi sayuran hijau segar yang mudah rusak atau busuk, bayam memerlukan penanganan khusus untuk memperpanjang masa simpannya. Salah satunya adalah dengan cara membuat tepung bayam dari sayuran bayam segar sehingga bisa dijadikan pengganti dalam pengolahan makanan tertentu. Pengolahan tepung bayam yang ditambahkan dalam pembuatan kue tradisional seperti Klepon merupakan salah satu bentuk pengembangan dalam pengolahan jajanan kue tradisional yang diharapkan dapat memberikan zat besi yang dibutuhkan bagi para penderita anemia.

Dari segi ekonomi maupun kesehatan, substitusi tepung bayam dalam pengolahan jajanan kue tradisional ini bisa menjadi alternatif bahan campuran yang bermanfaat bagi masyarakat. Kandungan gizi yang terkandung pada bayam serta harga yang terjangkau dan mudah didapat menjadi kelebihan bayam sebagai bahan subsitusi.Hal ini terbukti, menurut Badan Pusat Statistik bahwa pada 5 tahun terakhir, di Indonesia menghasilkan 893.204 Ton bayam pada tahun 20102015. Sangat disayangkan apabila penghasilan panen bayam tersebut tidak dapat digunakan dengan baik karna kurangnya penanganan khusus untuk memperpanjang masa simpannya. Oleh sebab itu penanganan seperti membuat tepung bayam bisa dijadikan salah satu solusi untuk memperpanjang masa simpan bayam.

\section{KAJIAN LITERATUR}

\section{A. Kue Klepon}

Kue Klepon adalah salah satu makanan tradisional Indonesia yang termasuk dalam kelompok jajanan pasar. Kudapan kue tradisional masih populer dan tetap menjadi favorit hingga sekarang karna harganya yang murah yang mudah didapat. Menurut Nimpuno (2016:56), Klepon yang kenyal dengan isi gula mempunyai makna bahwa terkadang sesuatu yang alot akan terasa manis dikemudian hari sesuai dengan usaha yang dilakukan.

Menurut Ari, Kue Klepon memiliki tekstur yang kenyal, padat, manis dan tidak memiliki daya simpan yang lama. Makanan ini terbuat dari 
tepung ketan putih yang diberi pewarna hijau baik dari daun suji ataupun daun pandan yang dicampur oleh santan kemudian dibentuk bulat-bulat diberi isian gula merah dan direbus didalam air mendidih. (qtd. In Sari, 2014:1)

Selama proses pembentukan, adonan Klepon harus ditutup oleh kain lembap agar tidak mengering dan retakretak. Hal ini akan beresiko membuat Klepon pecah ketika direbus. Bahkan untuk meminimalisir mengeringnya adonan, dianjurkan untuk langsung memasukkan adonan yang telat dibulatkan dan diberi isian ke dalam air yang mendidih. (Nimpuno, 2016:57).

Pada proses perebusan klepon, sebelum adonan dimasukan kedalam air, air yang didalam panci sudah harus dalam keadaan mendidih. Sebaiknya gunakan panci yang agak besar dan air yang cukup banyak agar pada saat klepon direbus, klepon tidak melekat satu sama lain. Klepon yang sudah matang akan mengapung, tetapi tunggulah sekitar 1-2 menit lagi sebelum diangkat agar klepon matang sempurna. (Nimpuno, 2016:25)

\section{B. Tepung Beras Ketan}

Tepung beras ketan adalah tepung yang dihasilkan dari proses penggilingan beras ketan yang putih dan bersih. Pada kue-kue tradisional, tepung ketan digunakan untuk pembuatan kue yang memiliki tekstur yang kenyal dan lengket (Imanningsih,2014:13).

Menurut Haryadi (2013:3-4), Beras ketan sebelum melalui proses penggilingan untuk dijadikan tepung beras ketan memiliki butir beras yang sebagian besar terdiri dari zat pati sekitar 80-85\% yang terdapat pada endosperma yang tersusun oleh granula-granula pati yang memiliki ukuran 3-10 milimikron. Karbohidra penyusun utama dari beras ketan adalah pati. Pati ketan memiliki kadar amilosa dibawah $1 \%$ pada pati beras ketan tersebut. Dimana patinya didominasi oleh amilopektin yang menyebabkan ketan akan sangat lekat jika dimasak.

Tepung beras ketan mengandung pati yang sangat berpengaruh terhadap pembuatan klepon. Pati tepung beras ketan ini berpengaruh pada proses gelatinisasi yang menyebabkan tekstur pada klepon ini kenyal.

Sukmaningrum, 2003:8)

Tepung ketan saat ini sudah sangat mudah didapatkan dipasaran. Menurut Badan Standarisasi Indonesia, tepung ketan yang dijual dipasaran harus sudah memenuhi Standar Nasional Indonesia, yaitu syarat mutu, cara pengambilan contoh, dan cara pengemasan untuk tepung ketan. Syarat tepung ketan yang digunakan untuk pembuatan Kue Klepon adalah harus berwarna putih bersih, halus, tidak ada kotoran, memiliki aroma khas beras ketan dan tidak berbau apek (SNI 014447-1998)

\section{Tepung Beras}

Tepung ini berasal dari beras (Oryza Sativa) yang ditumbuk hingga halus. Sifatnya paling sederhana dibanding tepung-tepung yang lainnya karena beras yang telah melalui fase proses pembersihan dan pemutihan dengan cara ditumbuk-tumbuk menyebabkan protein, vitamin dan mineral yang terkandung pada kulitnya tidak terbawa saat proses penumbukan. Tepung beras tidak mengandung gluten, oleh sebab itu tepung ini mudah larut dalam air pada suhu ruangan. Larutan tepung beras baru akan mengental dan menjadi lengket dengan cara dipanaskan secara perlahan-lahan. 


\section{Santan}

Santan merupakan turunan dari Cocos Nucifera, memiliki warna putih seperti susu dan rasanya manis gurih kelapa. Santan dihasilkan dari kelapa parut yang direndam air kemudian diperas. Air yang biasa digunakan untuk rendaman parutan kelapa adalah air biasa. Namun jika ingin menghasilkan santan yang lebih manis, maka gunakan air yang terkandung dalam kelapa utuh. (Sjoekri,2016:51-52)

Menurut Sjoekri (2016:52), Santan tersedia dalam bentuk segar maupun kemasan siap pakai. Santan kemasan siap pakai telah diolah melalui sistem pasteurisasi sehingga membuatnya sangat stabil dan tidak mudah pecah saat dimasak pada suhu panas. Santan segar juga mudah menjadi tengik pada suhu kamar, oleh sebab itu gunakan santan saat diperlukan dan simpan dalam lemari es sebelum digunakan.

Santan dari kelapa muda merupakan makanan berharga yang bagi penderita kekurangan protein dan vitamin D, serta tuberkoluse perut. (Rukmana \& Yadirachman. 2016:24).

Pada pembuatan Klepon, santan digunakan sebagai pengganti air untuk menguleni adonan. Sehingga rasa yang dihasilkan lebih gurih dibandingkan menggunakan air mineral biasa.

\section{E. Daun Pandan}

Pandan wangi atau orang biasa menyebutnya daun pandan, memiliki nama ilmiah Pandanus Amaryllifolius, merupakan tumbuhan purba yang diduga berasal dari kepulauan Maluku, yaitu daerah yang satu-satunya merupakan tempat spesimen ini ditemukan. Aroma wangi pandan bukan berasal dari minyak asirinya, melainkan dari pigmen karotenoid yang rusak dan teroksidasi. (Sjoekri,2016:163-165)

Untuk menghasilkan Klepon yang beraroma pandan, pandan dan suji dihaluskan dengan air, lalu disaring ampasnya dan sari hijiaunya digunakan sebagai pewarna serta menambah aroma dalam pembuatan Klepon.

\section{F. Daun Suji}

Pleomele Angustifolia adalah nama ilmiah dari daun suji. Bentuk daun suji mirip dengan daun pandan namun aromanya tidak sewangi daun pandan. Fungsi utama dari daun suji adalah memberikan pewarna hijau alami dalam pengolahan makan seperti Kue Klepon dan Cendol. (Sjoekri,2016:165)

Dalam pembuatan Klepon, daun suji digunakan untuk pemberi warna hijau alami. Menurut Sjoekri, (2016:165) Warna hijau yang terdapat pada daun suji dilepaskan dengan cara memotong atau menumbuk daunnya hingga memar lalu direndam dalam air sebelum daunnya di peras lalu diambil sari berwarna hijaunya. Teknik lainnya daun suji bisa dihaluskan menggunakan food processor lalu disaring untuk mendapatkan sari warnanya saja.

\section{G. Garam}

Garam memiliki nama ilmiah Natrium Klorida, secara umum garam memberikan rasa asin dan gurih pada setiap masakan. Sebagai pemberi rasa, garam sama sekali tidak memberikan jejak warna, tekstur, dan aroma pada masakan. Sifat inilah yang menjadikan garam sebagai bumbu paling mendasar dalam memasak. Teknik pembuatan garam sudah dikenal di Tionghoa sejak tahun 6000 SM. Karena sifatnya mudah menyerap air, garam dapat mengawetkan makanan antara lain ikan yang diasinkan dan diekspor ke Mesir di sekitar tahun 2800 SM. (Sjoekri,2016:60-61). 
Menurut Sjoekri (2016:60), di Indonesia, tambak garam banyak terdapat di daerah Madura dan Makassar. Air laut yang menguap, akan meninggalkan endapan kristal kotor berwarna abu abu. Untuk membersihkannya, endapan kristal ini dipindahkan sesuatu wadah lalu direndam bersama Natrium Karbonat selama semalam. Lalu air rendaman diluapkan lagi sehingga magnesium dan kalsium terbawa uap. Dari proses penguapan ini menghasilkan endapan garam putih yang bersih dan halus.

Dalam masakan, garam tidak hanya memberikan rasa asin tetapi memberikan rasa gurih pada makanan juga. Dalam hal lainnya, selain dapat dimanfaatkan sebagai pengawet makanan alami, garam juga menyehatkan tubuh pada porsi tertentu. Kandungan natrium pada garam sangat berguna untuk menjaga kadar garam pada darah agar tetap normal, yaitu $0,9 \%$ dari volume darah didalam tubuh. Kurangnya konsumsi natrium dapat menyebabkan tekanan darah menurun, denyut jantung meningkat, pusing disertai kram otot, daya ingat menurun, gangguan penglihat, kehilangan selera makan, serta terbentuknya bercak-bercak putih pada kuku. (Astawan, 2016:62-63)

Menurut National Research Council of The National Academy of Sciences, manusia mengkonsumsi natrium sebanyak $1.100-3.300$ miligram per hari atau setara dengan 0,5 $-1,5$ sendok teh garam dapur per hari untuk memenuhi kebutuhan natrium dalam tubuh. Dan untuk penderita hipertensi dianjurkan untuk mengkonsumsi garam tidak lebih dari 2.300 miligram per hari. Atau setara dengan enam gram atau satu sendok teh garam dapur. (qtd. in Astawan, 2016:63).
Dalam pembuatan Klepon, garam memberikan rasa asin dan gurih pada adonan tepung ketan yang sudah dicampurkan dengan santan.

\section{H. Gula Jawa}

Gula merupakan bahan pemanis yang mengandung energi yang mudah diserap oleh tubuh. Dari sumbernya, bahan pemanis ini dibedakan menjadi dua. Yakni, pemanis alami dan sintetis. Dari sumbangan energinya, pemanis dibedakan lagi menjadi nutritif dan nonnutritif. Salah satu contoh pemanis alami nutritif adalah gula jawa. (Astawan,2016:67)

Gula Jawa atau yang biasa disebut gula merah, ini merupakan gula olahan yang banyak digunakan di Pulau Jawa, terutama menjadi bahan baku pembuatan kecap. Gula jawa memberikan rasa manis dan gurih karena mengandung protein. Gula jawa perlu disimpan ditempat yang kering ataupun disimpan didalam lemari es. Karena sifat gula jawa cenderung lembap sehingga mudah meleleh dan mudah berjamur. (Sjoekri,2016:43)

Komposisi gizi gula merah sangat ditentukan oleh proses khas aroma dan citarasa yang khas serta kandungan mineralnya seperti kalsium, fosfor pengolahan serta jenis aren yang digunakan. Kandungan gizi utama yang terkandung dalam gula jawa adalah energi. Keunggulan gula jawa dibandingkan dengan gula pasir adalah ciri, dan zat besi. (Astawan,2016:69).

Gula Jawa yang digunakan sebagai isian Kue Klepon sebagai pemanis makanan, diisi dengan cara mengiris-iris Gula Jawa lalu dibuat sebagai isian. Gula Jawa yang meleleh akan memberikan rasa manis karamel dan aroma angit serta warna gelap cenderung cokelat pada saat Klepon digigit. 


\section{i. Kelapa Parut}

Kelapa miliki nama ilmiah Cocos Nucifera. Tanaman kelapa mempunyai sejarah panjang di Indonesia, bahkan sudah menjadi lambang pengenal kepulauan Indonesia. Dalam mitologi hindu dan menurut kitab suci weda, kelapa (Kalpa Vrikhsha-Bahasa Sansekerta) merupakan pohon surgawi. Konon, Dewa Wisnu membawa pohon kelapa sebagai sumber kesehatan, ketenangan, panjang usia dan kedamaian. (Rukmana \& Yudirachman,2016:15).

Kelapa parut merupakan hasil turunan dari pemarutan daging kelapa yang digunakan untuk taburan pada Kue Klepon. Biasanya daging kelapa harus dikupas atau diserut kulitnya terlebih dahulu untuk menghasilkan taburan kelapa parut yang putih bersih tanpa warna coklat dari kulit daging kelapa. (Sjoekri,2016:49). dengan

Menurut, (Astawan, 2016:116) kelapa parut dapat dibuat dalam keadaan segar, yaitu sesaat sebelum digunakan, dengan menggunakan cara tradisional. Cara ini tidak memerlukan teknik yang rumit karena pemarutan dilakukan menggunakan alat yang sederhana. Namun dewasa ini, pembuatan kelapa parut sudah dapat dilakukan secara modern karena adanya mesin pemarut yang dapat menghasilkan kelapa parut dengan cepat dan mudah. Kapasitasnya cukup besar sehingga dapat digunakan untuk memarut dalam skala besar. Bahkan di pasar-pasar tradisional maupun di swalayan, kini telah menjual kelapa parut dalam kemasan. Selain kemasan kelapa parut segar, kini juga tersedia pula kelapa parut kering (Dessicated Coconut) yang memiliki daya simpan yang lebih lama karena kadar airnya telah dihilangkan.
Kelapa parut dalam penggunaan taburan untuk kue klepon adalah kelapa diparut yang diberi garam sebagai penambah rasa gurih dan dikukus terlebih dahulu. Hal ini dilakukan karna buah kelapa olahan baik kelapa parut dan santan memiliki daya simpan yang tidak lama. (Nimpuno,2016:57).

\section{J. Minyak Kelapa}

Menurut Sjoekri (2016:176)

Minyak kelapa adalah minyak yang terbuat dari parutan kepala yang diberi air lalu diperas seperti membuat santan kemudian dimasak selama beberapa jam hingga sari dari minyak tersebut keluar dan mengambang ke permukaan serta meninggalkan ampas didasar permukaan wadah saat dilakukan proses pemanasan.

Menurut Rukmana dan Yudirachman (2016:24-25) karakteristik minyak kelapa ialah memiliki aroma yang khas, berwarna putih agak kuning, cair pada suhu kamar $\left(26-27^{\circ} \mathrm{C}\right)$ dan mengandung $84-93 \%$ Triasilgliserol. Triasilgliserol terdiri atas trisaturated $84 \%$, disaturated-monounsaturated $12 \%$ dan monosaturated-diunsaturated $4 \%$. Kandungan lainnya meliputi 1,2 diasil gliserol (1,5-5,1\%), 1,3 diasil gliserol (1,2-2,1\%), monoasil gliserol (1-7\%), asam lemak bebas (1-1,26\%), fosfolipid $(0,03-0,4 \%)$, glikolipid $(0,2-0,35 \%)$ dan sterols $(0,1 \%)$. Zat-zat tersebut antara lain berkhasiat obat dan perawatan kecantikan. Minyak kelapa juga membantu tubuh memerangi bakteri berbahaya seperti Listeria monocytogenes dan Helicobacter pylori.

Menurut Astawan (2016:159) Minyak kelapa juga membantu proses metabolisme lemak dalam tubuh sehingga mencegah terjadinya penyumbatan pembuluh darah, penyakit jantung koroner, dan penyakit degeneratif lainnya. 


\begin{abstract}
Pada pembuatan Klepon, minyak kelapa digunakan sebagai bahan campuran dalam adonan untuk memberikan aroma khas minyak kelapa dan sebagai bahan pembantu saat menguleni dna membuat bulat bulat adonan Klepon agar tidak lengket.
\end{abstract}

\section{K. Bayam}

Tanaman bayam merupakan salah satu jenis sayuran komersial yang mudah diperoleh disetiap pasar, baik pasar tradisional maupun pasar swalayan. Harganya pun dapat terjangkau oleh semua lapisan masyarakat. Tumbuhan bayam ini awalnya berasal dari negara Amerika beriklim tropis, namun sekarang tersebar keseluruh dunia. Hampir semua orang mengenal dan menyukai kelezatannya. Rasanya enak, lunak dan dapat memberikan rasa dingin dalam perut dan dapat memperlancar pencernaan. Umumnya tanaman bayam dikonsumsi bagian daun dan batangnya. Ada juga yang memanfaatkan biji atau akarnya sebagai tepung, obat, bahan kecantikan, dan lain-lain. (Bandini \& Azis, 2001)

Menurut Badan Pusat Statistik (2017), Pada 5 tahun terakhir dari 2010 hingga 2015, Indonesia menghasilkan bayam sebanyak 893.204 Ton. Pada tahun 2010 Indonesia menghasilkan 152.334 ton, tahun 2011 sebanyak 160.513, tahun 2012 sebanyak 155.118, pada tahun 2013 sebanyak 140.980, pada tahun 2014 sebanyak 134.166, dan pada tahun 2015 sebanyak 150.093.

Menurut Sunarjono (2016:28) bayam (Amaranthus sp.) merupakan satu-satunya sayuran yang termasuk dalam famili Amaranthaceae. Tanaman ini berbentuk perdu atau semak. Bayam sangat digemari di Indonesia karena rasanya enak, lunak dan dapat memperlancar pencernaan. Selain itu, bayam banyak mengandung Vitamin A dan C serta sedikit Vitamin B. Bayam pun banyak mengandung garam-garam mineral penting seperti kalsium, fosfor, dan zat besi.

Zat besi yang terkandung pada bayam berfungsi besar sebagai pusat pengaturan molekul hemoglobin sel-sel darah merah. Hemoglobin berpengaruh terhadap pendistribusian oksigen dari paru-paru ke seluruh tubuh. Zat besi juga berperan sebagai metabolisme energi, termasuk sistesis DNA oleh beberapa Enzim, serta dalam sistem kekebalan tubuh (Wirakusumah, 2017:11-12)

Kandungan zat besi bayam hijau yang lebih tinggi dibandingkan dengan bayam merah ini sangat bermanfaat bagi penderita anemia. Kandungan zat besi pada bayam hijau juga lebih tinggi dibandingkan dengan sayuran hijau lainnya. Namun, seperti sayuran lainnya, zat besi pada bayam sukar di serap oleh tubuh. Untuk mempermudah penyerapannya, sebaiknya mengkonsumsi bayam bersama dengan sumber makanan lain. ( Rizki. 2013:18 )

Menurut Peraturan Menteri Kesehatan Republik Indonesia Nomor 41 tentang Pedoman Gizi Seimbang (2014:74-75) Kebutuhan zat besi bagi remaja putri dan perempuan dewasa diperlukan untuk membentuk hemoglobin yang mengalami peningkatan dan mencegah anemia yang disebabkan karena kehilangan zat besi selama menstruasi. Asam folat digunakan untuk pembentukan sel dan sistem saraf termasuk sel darah merah. Asam folat berperan penting pada pembentukan DNA dan metabolisme asam amino dalam tubuh. Kekurangan asam folat dapat mengakibatkan anemia karena terjadinya gangguan pada pembentukan DNA yang mengakibatkan 
gangguan pembelahan sel darah merah sehingga jumlah sel darah merah menjadi kurang. Asam folat bersamasama dengan vitamin B6 dan B12 dapat membantu mencegah penyakit jantung. Seperti halnya zat besi, asam folat banyak terdapat pada sayuran hijau, kacang-kacangan, dan biji-bijian.

Dalam mengkonsumsi bayam pun harus diperhatikan pengolahannya, karena semakin lama bayam disimpan didalam lemari es, senyawa nitrit $\left(\mathrm{NO}_{2}\right)$ yang bersifat racun kadarnya akan terus meningkat. Efek racun iniakan berdampak pada sel darah merah, yaitu hemoglobin. Ikatan nitrit dengan hemoglobin akan menyebabkan hemoglobin kehilangan kemampuannya dalam mengikat oksigen. Oleh sebab itu, salah satu cara penyimpanan yang lebih aman agar daya simpan bayam lebih lama dengan cara membuat tepung. (Rizki. 2013:19).

\section{Tepung Bayam}

Menurut Tabel Pangan

Komposisi Pangan Indonesia (2009:17), kadar air yang terkandung pada bayam adalah $86,9 \%$ hal inilah yang menyebabkan daya simpan bayam sangat rendah. Salah satu hal yang dapat dilakukan untuk mencegah kerusakannya adalah dengan pengeringan. Lalu bentuk akhir dari proses pengeringan tersebut adalah dengan dibuatnya tepung bayam.

Pembuatan tepung bayam akan meningkatkan keanekaragaman pemanfaatan bayam dan yang lebih penting adalah untuk menjadikannya sebagai sumber Zat Besi serta sebagai penambah warna pangan. Dalam bentuk tepung daya simpannyaakan meningkat, dan transportasinya mudah serta penggunaan lanjutnya pun lebih mudah daripada dalam bentuk segar.

Pada penelitian Hadiningsih (1999:28) tahap kritis dalam pembuatan tepung adalah tahap pemblansiran. Perebusan dilakukan pada suhu $90^{\circ} \mathrm{C}$ selama 5 menit, dengan tujuan untuk menurunkan aktivitas enzim phenolase yang merusak karotenoid dalam sayuran, sehingga sayur tetap berwarna hijau. Pengeringan dilakukan menggunakan oven dengan suhu $60^{\circ} \mathrm{C}-70^{\circ} \mathrm{C}$ selama 4 jam. Pengeringan oven memiliki kelebihan dapat mempertahankan karoten dan klorofil agar warna tepung tetap hijau dan tidak mengalami pencoklatan. 


\section{Cara Pembuatan Tepung Bayam}

Persiapan alat memasak dan bahan termasuk mencuci bayam dan memisahkan daun bayam dari batangnya.

\section{II}

Penimbangan bayam menggunakan timbangan digital. Bahan yang ditimbang hanya daun bayam

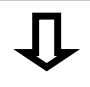

Pemblansiran bayam menggunakan panci berisi air mendidih dengan suhu $90^{\circ} \mathrm{C}$ selama 60 detik

\section{$\sqrt{1}$}

Pengeringan daun bayam dilakukan menggunakan Pemanggang (Oven) dengan suhu $150 \mathrm{oC}$ selama 45 menit

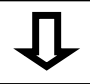

Penghalusan daun bayam yang telah dikeringkan menggunakan Blender selama 5 menit

\section{$\sqrt{ }$}

Pengayakan tepung bayam yang telah dihaluskan menggunakan ayakan tepung untuk memisahkan tepung bayam dari seratnya

\section{Sumber: Data Primer Modifikasi}

Simanjuntak, (2016:26)

\section{Cara Pembuatan Klepon}

Persiapan alat dan bahan

Penimbangan bahan-bahan kering dan bahan-bahan cair menggunakan

timhanoan dioital secuai denoan recen

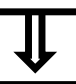

Pencampuran bahan kering dan bahan cair lalu diuleni hingga menjadi adnnan vano kalis

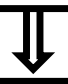

Pembentukan dan pengisian adonan dengan gula merah dengan berat adnnan kelennn 17 or dan ician oula

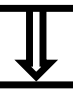

Perebusan klepon dengan air mendidih dengan suhu $100^{\circ} \mathrm{C}$ yang ditamhahkan daun nandan selama 5 -

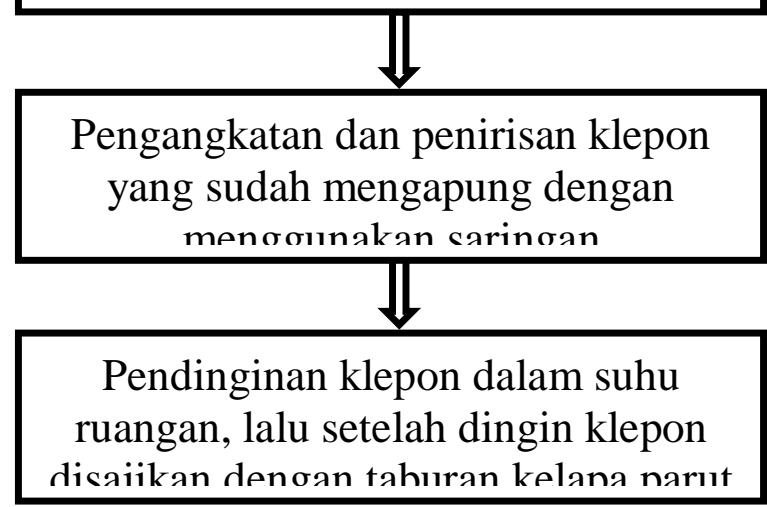

Sumber : Data Primer ModifikasiIndriani, (2016:57) 


\section{METODE PENELITIAN}

Metode penelitian menurut Sugiyono (2004: 24) merupakan cara ilmiah untuk mendapatkan data dengan tujuan dan kegunaan tertentu. Metode penelitian yang digunakan penulis dalam penelitian ini berupa metode eksperimental.

Metode penelitian yang digunakan penulis adalah Metode Eksperimental Kuantitatif. Menurut Faisal, Metode eksperimental ialah upaya peneliti secara sengaja memanipulasi suatu variabel (dengan maksud untuk memunculkan atau tidak memunculkan suatu variabel) kemudian memeriksa efek atau akibat yang ditimbulkan. (qtd. In Purwanto \& Sulistyastuti, 2017:84) sedangkan data kuantitatif adalah data yang berupa angka-angka seperti, untuk pembuatan Klepon dibutuhkan 100gram tepung ketan dan bahan cair yang terdiri dari santan dan pewarna daun suji $45 \mathrm{ml}$.

Dengan adanya logika yang demikian menyebabkan dalam penelitian eksperimental terdapat 2 variabel yang disebut sebagai "Kelompok Kontrol" dan "Kelompok Eksperimental (treatment atau perlakuan)". Kelompok kontrol adalah kelompok yang dibiarkan tanpa adanya perlakuan sedangkan kelompok eksperimental adalah kelompok yang diberi perlakuan tertentu. (Purwanto \& Sulistyastuti, 2017:84)

Pada penelitian ini, yang menjadi kelompok Kontrol adalah Klepon tanpa substitusi tepung bayam dan sebagai kelompok perlakuan adalah Klepon dengan substitusi tepung bayam 30\%, $60 \%$ dan $90 \%$.

Panelis tidak terlatih (Untrained Panel) terdiri dari 25 orang awam yang dapat dipilih berdasarkan jenis suku- suku bangsa, tingkat sosial dan pendidikan. Panelis tidak terlatih hanya diperbolehkan menilai sifat-sifat yang sederhana seperti sifat kesukaan, tetapi tidak boleh digunakan dalam uji pembedaan. Panel tidak terlatih biasanya terdiri dari orang dewasa dengan komposisi panelis pria sama dengan panelis wanita.

\section{PEMBAHASAN}

Berdasarkan hasil analisis data pada Uji Pembedaan, menghasilkan fakta bahwatidak terdapat perbedaan signifikan pada segi rasa. Tidak adanya perbedaan signifikan pada segi rasa disebabkan karna proses pemblansiran daun bayam yang dilakukan pada suhu $90^{\circ} \mathrm{C}$ selama 60 detik yang menyebabkan menurunnya aktivitas enzim phenolase yang berbau langu khas bayam ini berkurang. Sehingga tepung yang dihasilkan sudah tidak berbau langu yang menyengat khas bayam. Hal inilah yang menyebabkan aroma dan rasa bayam sudah tidak terasa dan didominasi oleh rasa dari bahan-bahan lainnya yang digunakan pada pembuatan klepon.

Berdasarkan hasil analisis data pada Uji Pembedaan, menghasilkan fakta bahwa terdapat perbedaan signifikan pada segi warna dan segi tekstur.

Perbedaan signifikan dari segi warna ini terjadi karena disebabkan oleh adanya zat hijau daun (Klorofil) pada daun suji dan daun pandan serta penambahan tepung bayam itu sendiri yang juga mengandung zat hijau daun (Klorofil) sehingga warna pada Klepon dengan substitusi tepung bayam 30\% dengan kode 4313, 60\% dengan kode 5626 dan 90\% dengan kode 4959 yang 
dihasilkan lebih hijau pekat dibandingkan produk kontrol dengan kode produk 2041 yang hanya mendapatkan warna hijau dari daun suji dan daun pandan. Semakin banyak persentase tepung bayam maka semakin pekat pula Klepon Bayam yang dihasilkan.

Perbedaan signifikan dari segi tekstur disebabkan karena berkurangnya pati yang terkandung pada tepung beras ketan yang memiliki sifat dasar membuat kenyal suatu adonan atau bahan makanan karena adanya pengurangan tepung beras ketan pada produk perlakuan Klepon dengan substitusi tepung bayam 30\% dengan kode 4313, $60 \%$ dengan kode 5626 dan $90 \%$ dengan kode 4959 sehingga produk yang dihasilkan mengalami kekurangan kekenyalan pada segi tekstur dibandingkan dengan produk kontrol dengan kode 2041 yang lebih banyak mengandung pati tepung beras ketan. Semakin sedikit persentase tepung beras ketan, maka semakin sedikit pula pati yang terkandung pada Klepon dengan substitusi tepung bayam sehingga kekenyalan pada Klepon juga semakin menurun.

Namun setelah melalui analisis data pada Uji Kesukaan atau Uji hedonik, menghasilkan fakta bahwa produk perlakuan kedua yaitu Klepon dengan substitusi tepung bayam $30 \%$ dengan kode produk 4313 menjadi produk yang paling disukai oleh para panelis dibanding dengan produk kontrol. Hal ini dibuktikan karena nilai rata-rata keseluruhan Uji Kesukaan pada produk perlakuan pertama dengan kode produk 4313 nilai rata-rata 3,33 yang menunjukan niali interpretasi taraf kesukaan "Sangat Suka".

Namun hal ini tidak berbeda signifikan dengan produk kontrol, karena produk kontrol dengan kode 2041 memiliki nilai rata-rata keseluruhan 3,25 yang juga menunjukan kriteria interpretasi taraf kesukaan "Suka" . Perbedaan nilai rata-rata keseluruhan tidak berbeda signifikan antara produk 4313, yaitu Klepon dengan subtitusi tepung bayam $30 \%$ dan produk kontrol 2041 Klepon tanpa tepung bayam yang hanya terpaut perbedaan nilai rata-rata keseluruhan 0,08 pada Uji Kesukaan atau Uji Hedonik.

Pada produk perlakuan kedua yaitu Klepon dengan susbtitusi tepung bayam $60 \%$ dengan kode 5626 memiliki nilai rata-rata kesukaan keseluruhan 2,92 yang menunjukan kriteria interpretasi taraf kesukaan "Suka". Dan pada produk perlakuan ketiga yaitu Klepon dengan substitusi tepung bayam 90\% dengan kode 4959 yang memiliki nilai rata-rata kesukaan keseluruhan 2,33 yang menunjukan kriteria interpretasi taraf kesukaan "Tidak Suka". Hal ini disebabkan karna adanya perbedaan yang signifikan antara rasa, aroma, tekstur dan warna, sebagai berikut:

Nilai rata-rata Uji Perbedaan dari segi rasa 2,00 yang menunjukan "Berasa Bayam".

Nilai rata-rata Uji Perbedaan dari segi tekstur dengan nilai 1,8 yang menunjukan "Kurang Kenyal".

Nilai rata-rata Uji Perbedaan dari segi warna dengan nilai 1,8 yang menunjukan "Hijau Tua".

Hal ini lah yang menyebabkan kenapa produk Klepon dengan substitusi tepung 
bayam 90\% dengan kode 4959 tidak disukai oleh panelis.

\section{PENUTUP}

Adanya perbedaan yang signikan dari segi tekstur dan warna pada Klepon dengan substitusi tepung bayam dengan nilai signifikan $0,020<0,050$ pada segi tekstur dan nilai signifikan $0,024<0,050$ pada segi warna

Tidak adanya perbedaan signifikan dari segi rasa pada Klepon dengan substitusi tepung bayam dengan nilai signifikan pada segi rasa adalah $0,068>0,050$.

Penelitian ini dapat dilanjutkan sampai mendapatkan hasil yang maksimal dari segi warna dalam pembuatan kue klepon dengan substitusi tepung bayam tanpa harus memberikan penambahan pewarna makanan karena sudah terdapat pewarna alami pada tepung bayam itu sendiri.

Penelitian ini dapat dilakukan dalam pembuatan kue klepon dengan substitusi tepung bayam sebanyak $30 \%$ dan $60 \%$ karena menunjukan hasil yang disukai oleh para panelis.

Peneliti selanjutnya dapat menggunakan tepung bayam ini sebagai difortifikasi makanan serta sebagai tepung bebas gluten maupun pewarna makanan alami pada jenis pastry lainnya yang bagi anak-anak yang tidak menyukai sayuran.

Pemanfaatan sayuran yang mudah dan murah seperti bayam ini diharapkan bisa menjadi pemicu untuk lebih berinovasi pada makanan khususnya pastry atau pun jajanan pasar Indonesia.

Penelitian selanjutnya diharapkan melakukan Uji Kimiawi pada Klepon yang sudah disubstitusikan dengan tepung bayam untuk mengetahui zat kimiawi yang terkandung, berapa persenkah zat kimiawi yang terkandung pada klepon yang berkurang pada saat proses pemasakan atau perebusan itu berlangsung.

\section{REFERENSI}

Chaves, H.M., Paulo., Ashar Bimal., Guralnik M., Jack Fried., Linda. (2002). Association Between Mild Anemia and Executive Function Impairment in Community-Dwelling Older Women: The Women's Health and Aging Study II;50;1257-1264

Departemen Kesehatan Republik Indonesia (2014). Menkes Buka Persagi Dan Temu Ilmiah Internasional Persatuan Gizi Indonesia Tahun 2014. Bina Kesehatan Masyarakat. Jakarta. http://www.depkes.go.id/article/v iew/14120300002/menkes-bukakonas-persagi-dan-temu-ilmiahinternasional-persatuan-ahli-giziindonesia-tahun-2014[16 Januari 2015]

Survei Sosial Ekonomi Nasional. (2017) Basis Data Konsumsi Pangan; Konsumsi per Kapita dalam Rumah Tangga Setahun Menurut Hasil Susenas 2017. Kementrian Pertanian. Jakarta. http://aplikasi2.pertanian.go.id/ko nsumsi/tampil_susenas_kom2_th. php.

Tria. (2005). Kampaye Indonesia Bebas Anemia 2005. Varia Warta Indonesia, Jakarta

Pracaya, Ir., \& Juang Gema Kartika S.P., M.Si. (2016) Bertanam 8 
Sayuran Organik. Penebar Swadaya. Jakarta

Nimpuno, Diah. (2016). Nostalgia Kue Tenong. Gramedia Pustaka Utama, Jakarta

Sari, Febrina, Debora. (2014). Pengaruh Substitusi Tepung Beras dengan Ubi Jalar Ungu Terhadap Karakteristik "Klepon” yang

Dihasilkan. Skripsi Universitas Udayana. Bali

Imanningsih, Ines. (2012). Penel Gizi Makanan: Profil Gelatinisasi beberapa profil tepung tepungan; 35;13-22

Haryadi. (2013)Analisa Kadar Alkohol Hasil Fermentasi Ketan dengan Metode Kromatografi Gas dan Uji Aktifitas Saccharomyces Cereviceae Secara Mikrokopis. Tugas Akhir Universitas Diponegoro. Semarang.

Sukmaningrum, Atik. (2003). Formulasi Makanan Berkalori Tinggi (Pangan Darurat) Dari Buah Sukun (Artocarpus Altilis). Skripsi Institut Pertanian Bogor. Jawa Barat

Sjoekri, Rima. (2016). Seni rasa. Gramedia Pustaka Utama, Jakarta

Rukmana, H. Rahmat\& H. Hardi Yudirachman (2016). Untung Berlipat dari Budidaya Kelapa Tanaman Multi Manfaat. Lily Publisher, Yogyakarta.

Astawan, Made. (2016). Sehat Dengan Rempah dan Bumbu Dapur. Kompas Media Nusantara, Jakarta

Bandini, Yusni. \& Azis, Nurudin. (2001). Bayam. Penebar Swadaya, Jakarta
Badan Pusat Statistik. (2017). Produksi Tanaman Sayuran, Holtikultura. Produk Sayuran Bayam (Ton) Tahun 2010-2015. Badan Pusat Statistik. Jakarta. https://www.bps.go.id/site/result $\underline{\text { Tab }}$ [22 Juli 2017]

Wirakusumah, Emma. S. (2007). Jus Buah dan Sayuran. Penebar Swadaya, Jawa Barat

Rizki, Farah. (2013). The Miracle of Vegetable. AgroMedia Pustaka, Jakarta

Hadiningsih, N. (1999). Pemanfaatan Tepung Jagung Sebagai Bahan Pensubstitusi Terigu Dalam Pembuatan Produk Mie Kering yang Difortitifikasi Dengan Tepung Bayam. Skripsi Fakultas Teknologi Pertanian Institut Pertanian. Bogor

Purwanto, Agus, Erwan, Ph.D., \& Diah Ratih Sulistyastuti M.Si. (2017). Metode Penelitian Kuantitatif Untuk Administrasi Publik Dan Masalah-Masalah Sosial. Gava Media. Yogyakarta.

\section{BIODATA PENULIS}

1. Chairul Salim adalah dosen di Sekolah Tinggi Pariwisata Trisakti, latar belakang pendidikan penulis adalah Magister Pariwisata Sekolah Tinggi Pariwisata Trisakti, Mata kuliah Yang diampu adalah Manajemen Pengolahan Roti dan Kue.

2. Vienna Artina Sembiring adalah dosen di Sekolah Tinggi Pariwisata Trisakti, latar belakang penulis adalah Lulusan Diploma IV Sekolah Tinggi Pariwisata Trisakti dan Magister pendidikan Bahasa Inggris Universitas Indraprasta PGRI Jakarta. Mata kuliah yang diampu adalah Housekeeping dan 
Bahasa Inggris.Beberapa makalah yang disusun penulis sudah dipresentasikan dalamForum International seperti pada Konfrensi Asia Tourism Forum 2016, International Conference on Tourism, Gastronomy, and Tourist Destination 2016 dan International Geography Seminar 2017.

3. Alisha Sekar Ayu Mahasiswa lulusan Sekolah Tinggi Pariwisata Trisakti dan bekerja dibagian pastry. 